\title{
Vascular function in arteries of intertidal fish Girella laevifrons (Kyphosidae)
}

\author{
Moraga, FA. ${ }^{a *}$ and Urriola-Urriola, $N .^{a}$ \\ aLaboratorio de Fisiología, Hipoxia y Función Vascular, Departamento de Ciencias Biomédicas, Facultad de Medicina, \\ Universidad Católica del Norte - UCN, Campus Guayacán, Larrondo, 1281, CP 117, Coquimbo, Chile \\ *e-mail: fmoraga@ucn.cl
}

Received: March 19, 2013 - Accepted: May 14, 2013 - Distributed: August 31, 2014

(With 1 figure)

\begin{abstract}
Preliminary studies showed that dorsal artery contraction mediated by acetylcholine (ACh) is blocked with indomethacin in intertidal fish (Girella laevifrons). Our objective was to characterise the cholinergic pathway in several artery vessels of the G. laevifrons. Afferent and efferent branchial, dorsal and mesenteric arteries were dissected of 6 juvenile specimens, isometric tension studies were done using dose response curves (DRC) for Ach $\left(10^{-13}\right.$ to $\left.10^{-3} \mathrm{M}\right)$, and cholinergic pathways were obtained by blocking with atropine or indomethacin. CRC to ACh showed a pattern of high and low sensitivity. Furthermore, these contractions were blocked in the presence of atropine and indomethacin in all vessels. Our results suggest that contraction observed with acetylcholine is mediated by receptors that activate a cyclooxygenase contraction pathway.
\end{abstract}

Keywords: intertidal fish, vascular reactivity, acetylcholine, atropine, indomethacin, cycloxygenase.

\section{Função vascular nas artérias do peixe marinho Girella laevifrons (Kyphosidae)}

\begin{abstract}
Resumo
Estudos preliminares mostraram que a contração da artéria dorsal mediada por acetilcolina (ACh) é bloqueada com indometacina em peixes marinhos Girella laevifrons. Nosso objetivo foi caracterizar a via colinérgica em várias artérias de G. laevifrons. Artérias aferentes e eferentes branquiais, dorsais e mesentéricas foram dissecadas de 6 espécimes juvenis. Os estudos de tensão isométrica foram feitos utilizando-se a curva dose - resposta (CDR) para Ach $\left(10^{-13} \mathrm{a}\right.$ $10^{-3} \mathrm{M}$ ), e identificaram-se as vias colinérgicas, bloqueando com atropina e indometacina. CRC para ACh mostrou um padrão de alta e baixa sensibilidade. Essas contrações foram bloqueadas na presença de atropina e indometacina em todas as artérias avaliadas. Nossos resultados sugerem que a contração observada com acetilcolina é mediada por receptores muscarínicos que ativam uma ciclo-oxigenase.
\end{abstract}

Palavras-chave: peixes intertidais, reatividade vascular, acetilcolina, atropina, indometacine, ciclo-oxigenase.

\section{Introduction}

Intertidal fish represent a complex organism tolerant to extreme conditions in the microhabitats of pools during low tide. Girella laevifrons is the most abundant fish species inhabiting the rocky intertidal zone along the Chilean coast (Varas and Ojeda, 1990; Muñoz and Ojeda, 1997; Ojeda et al., 2000). In addition, it is a transitory species that only inhabits these environments during the juvenile stage and later migrates to the subtidal zone (Pulgar et al., 1999). Accordingly, preliminary results obtained in our laboratory, performed in the dorsal artery in Girella laevifrons (intertidal specie), showed a powerful vasoconstriction induced by acetylcholine (Ach) mediated by cyclooxygenase (COX) (Urriola and Moraga, 2008), suggesting a coupled mechanism between muscarinic receptors and vasoconstriction mediated by this way.
Our objective was to characterise the cholinergic pathway using antagonists such as atropine (At) and indomethacin (IND) in the afferent branchial, efferent branchial, mesenteric and dorsal arterial vessels in the intertidal fish Girella laevifrons.

\section{Material and Methods}

\subsection{Animals}

Six juvenile Girella laevifrons (Kyphosidae) were extracted during low tide in the Totoralillo bay $\left(30^{\circ} 17^{\prime} \mathrm{S}\right.$, $71^{\circ} 31^{\prime} \mathrm{W}$ ) south of Coquimbo, Chile. All specimens were taken to the laboratory at the Universidad Católica del Norte and maintained for 3-5 days in filtered recirculation 
containers of fresh water at $15{ }^{\circ} \mathrm{C}$. Afterwards, corporal mass $(120 \pm 16 \mathrm{~g})$ and longitude oral-tail $(19 \pm 0.4 \mathrm{~cm})$ were measured for each specimen. Prior to experimentation, G. laevifrons were anaesthetised with benzocaine (1:1000) and sacrificed by decapitation.

\subsection{Bath organ physiology}

After decapitation, arterial vessels were carefully dissected from the following areas: branchial afferent (ABA), branchial efferent (ABE), dorsal (DA) and mesenteric (MA) and placed in cold $\left(4^{\circ} \mathrm{C}\right)$ physiological saline solution (PSS). The PSS contained (in $\mathrm{g} / \mathrm{L}$ ): $\mathrm{NaCl} 7.37, \mathrm{KCl} 0.31, \mathrm{KH}_{2} \mathrm{PO}_{4}$ $0.46, \mathrm{Na}_{2} \mathrm{HPO}_{4} 2.02, \mathrm{MgSO}_{4} 0.14, \mathrm{CaCl}_{2} 0.1$, glucose 0.9 with $\mathrm{pH}$ adjusted to 7.8 (Olson and Villa, 1991). Individual arterial ring segments of $2 \mathrm{~mm}$ length were mounted in a four channel small vessel wire myograph (model 610M Danish Myotech, Aarhus, Denmark). The vessels were threaded onto two tungsten wires of $40 \mu \mathrm{m}$ in diameter and attached to a force transducer and a micrometer for isometric measurements. All signals were acquired by a system acquisition (Powerlab 8sp, ADInstrument, Australia) and the data collected on a personal computer for further analysis. After mounting the rings, the arterial segments were incubated in PSS at $15^{\circ} \mathrm{C}$ and gassed with air for $30 \mathrm{~min}$. Each vessel segment was stretched to its optimal diameter, i.e. the diameter at which it developed a contraction response to PSS- $\mathrm{K}^{+}$, using a diameter-tension protocol as previously described for mammalian small arteries (Stassen et al., 1997). In this way, the myograph permitted direct measurement of vessel wall tension while the internal diameter was controlled.

Following an equilibration period of at least $30 \mathrm{~min}$, dose response curves (DRC) were performed for $\mathrm{KCl}$ (5.6-125 mM) and the cholinergic agonist acetylcholine (Ach) at concentrations ranging from $10^{-13}$ at $10^{-3} \mathrm{~mol} / \mathrm{L}$. Afterwards, DRC to Ach were performed in vessels pre-incubated for 30 min with At, $10^{-5} \mathrm{M}$, an Ach receptor antagonist; and indomethacin IND, $10^{-5} \mathrm{M}$, a cyclooxygenase (COX) inhibitor. Between experiments, the arterial preparations were allowed to recover for at least 30-60 min to return to resting basal tension.

For the PSS- $\mathrm{K}^{+}$solution $(125 \mathrm{mM} \mathrm{KCl}), \mathrm{NaCl}$ was replaced by an equimolar amount of $\mathrm{KCl}$. All chemicals were reagent grade and purchased from Sigma Chemical (St Louis, MO, USA). The following drugs used in the study: Ach, At and IND were purchased from Sigma Chemical (St Louis, MO, USA).

\subsection{Data analysis and statistics}

$\mathrm{CRC}$ were analysed in terms of maximal response (Rmax), sensitivity $\left(\mathrm{EC}_{50}\right.$ or $\left.\mathrm{pEC}_{50}\right)$ and maximum dilation (Dmax) to different contractile agents by fitting the individual data with a nonlinear sigmoid regression curve (Prism 4.0, Graphpad, San Diego, CA, USA). Rmax was expressed as $(\mathrm{mN} / \mathrm{mm})$. Sensitivity was expressed as $\mathrm{EC}_{50}$ (the concentration of agonist at which $50 \%$ of Rmax was obtained) or as $\mathrm{pEC}_{50}\left(-\log \mathrm{EC}_{50}\right)$.

All results were expressed as mean \pm SEM. A two way ANOVA for repeated measurements was used for statistical analysis of physiological variables. Differences were considered significant when $p<0.05$ (Primer of Biostatistical v 3.0, Mc Graw Hill).

\section{Results}

\subsection{Response to potassium chloride $(\mathrm{KCl})$}

Table 1 provides a summary for the parameter $\mathrm{EC}_{50}$ and Rmax obtained from the analysis of the arterial response curves. No differences were observed in the $\mathrm{EC}_{50}$ in any of the arteries evaluated. In contrast, Rmax increased significantly in the dorsal artery when compared to those obtained from the other vessels.

\subsection{Responses to acetylcholine}

Comparison of all vascular beds showed that DA and MA had a higher tension to Ach than ABA and ABE (Figure 1). DRC revealed a pattern of higher sensitivity with lower doses $\left(10^{-13}-10^{-10} \mathrm{M}\right)$ of Ach and lower sensitivity with higher doses $\left(10^{-6}-10^{-3} \mathrm{M}\right)$ of Ach. Lower concentrations

Table 1. Data obtained from concentration response curves in several vascular areas of G. laevifrons.

\begin{tabular}{|c|c|c|c|c|}
\hline & ABA & EBA & MA & DA \\
\hline \multicolumn{5}{|l|}{ CCR-K ${ }^{+}$} \\
\hline $\mathrm{EC}_{50}(\mathrm{mM})$ & $23.8 \pm 9.1$ & $28.8 \pm 8.8$ & $26.6 \pm 2.2$ & $26.0 \pm 7.0$ \\
\hline $\operatorname{Rmax}(\mathrm{mN} / \mathrm{mm})$ & $1.44 \pm 0.17$ & $1.72 \pm 0.25$ & $1.54 \pm 0.09$ & $2.50 \pm 0.82 *$ \\
\hline \multicolumn{5}{|l|}{ CCR-Ach } \\
\hline $\mathrm{pEC}_{50}(\mathrm{mM})$ & $-4.79 \pm 0.21$ & $-4.99 \pm 0.29$ & $-10.30 \pm 0.7 * \dagger$ & $-4.87 \pm 0.22 \ddagger$ \\
\hline $\operatorname{Rmax}(\mathrm{mN} / \mathrm{mm})$ & $0.84 \pm 0.02$ & $0.68 \pm 0.06$ & $1.47 \pm 0.09 *$ & $3.87 \pm 0.16^{* \dagger \dagger}$ \\
\hline \multicolumn{5}{|l|}{$\mathrm{At}+\mathrm{CCR}-\mathrm{ACh}$} \\
\hline $\mathrm{pEC}_{50}(\mathrm{mM})$ & $-6.97 \pm 0.26$ & $-9.50 \pm 0.3^{*}$ & $-9.27 \pm 0.23^{*}$ & $-8.07 \pm 0.41 *$ \\
\hline $\operatorname{Rmax}(\mathrm{mN} / \mathrm{mm})$ & $0.13 \pm 0.02+$ & $0.17 \pm 0.01+$ & $0.81 \pm 0.03+$ & $0.29 \pm 0.02+$ \\
\hline \multicolumn{5}{|l|}{ IND+ CCR-ACh } \\
\hline $\mathrm{pEC}_{50}(\mathrm{mM})$ & $-5.23 \pm 0.04$ & $-5.75 \pm 0.45$ & $-4.93 \pm 0.25$ & $-6.37 \pm 0.29 *+t$ \\
\hline $\operatorname{Rmax}(\mathrm{mN} / \mathrm{mm})$ & $0.33 \pm 0.04+$ & $0.18 \pm 0.02+$ & $0.61 \pm 0.05 \dagger+$ & $0.84 \pm 0.06 \dagger+$ \\
\hline
\end{tabular}

Mean \pm s.e.m; *vs ABA, $\mathrm{P}<0.05$; †vs $\mathrm{ABE}, \mathrm{P}<0.05$; †vs MA, $\mathrm{P}<0.05 ;+\mathrm{P}<0.05$ vs Ach. 


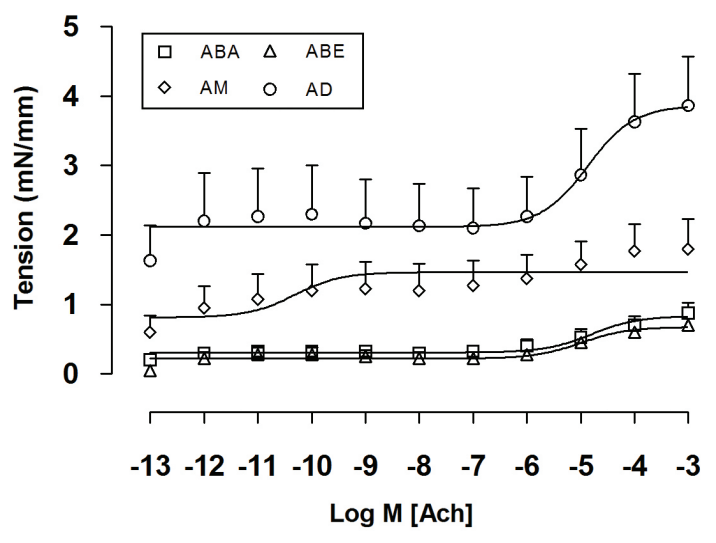

Figure 1. Acetylcholine doses-response curves of isolated rings from: Afferent branchial artery (ABA, open squares); efferent branchial artery (EBA, open triangles); mesenteric artery (MA, open rhombus) and dorsal artery (DA, open circles). Each symbol represents the mean \pm S.E.M.

of Ach produced an increase in tension close to $30 \%$ of the maximal response in all the vessels studied. Table 1 summarises the $\mathrm{pEC}_{50}$ and $\mathrm{Rmax}$ values obtained from analysis of the arterial curves. A major $\mathrm{pEC}_{50}$ was observed in MA as compared to ABA, ABE and DA. However, a higher Rmax was found in the dorsal artery as compared to those observed in the other vessels.

\subsection{Response blockade with Atropine}

In order to evaluate if the arterial contraction observed in the presence of Ach was blocked with At $\left(10^{-5} \mathrm{M}\right)$, DRC to Ach were performed in all arterial vessels in the presence of atropine (Figure 1). The data shows that both the high and low sensitivity contractions were abolished in the presence of At. The major effect of blockade with At was observed in the dorsal artery as compared to ABE, ABA and AM. Table 1 summarises the $\mathrm{pEC}_{50}$ and Rmax values obtained from analysis of the arterial curves.

\subsection{Response blockade with IND}

In order to evaluate the mechanism of contraction or dilation effect induced by Ach, we blocked with IND $\left(10^{-5} \mathrm{M}\right)$ and DRC to Ach were performed in all arterial vessels (Figure 1). High sensitivity contractions induced by Ach was blocked by IND in DA and MA, without any observed effect in ABE. However, the low sensitivity contraction observed induced by Ach was attenuated. Table 1 summarises the $\mathrm{pEC}_{50}$ and Rmax values obtained from analysis of the arterial curves.

\section{Discussion}

Our study demonstrates for the first time that intertidal fish G. laevifrons possess a vasoconstrictor mechanism for high sensitivity mediated by Ach indicating the presence of two muscarinic receptors: one high of sensitivity and a second of lower sensitivity coupled to different mechanisms of activation.

\subsection{Vascular response to acetylcholine}

Our results show that all vessels studied (ABA, EBA, MA and DA) express a vasoconstriction mediated by Ach. The vasoconstriction observed in G. laevifrons suggests the presence of two receptor populations present in the vascular artery. The first response was characterised by a high sensitivity to a range of $10^{-13}$ to $10^{-10} \mathrm{M}$ of Ach; this response was $30-50 \%$ of the maximum response. A high sensitivity response to Ach was previously described in perfused trunks in cod (Gadus morhua) spleen which displayed contractions to Ach at concentrations between $10^{-10}$ and $2 \times 10^{-9} \mathrm{M}$ (Nilsson and Grove, 1974). Head isolation preparations in the icefish Chionodraco hamatus (Pellegrino et al., 2003) exhibited a $30 \%$ maximum contraction response to Ach $\left(10^{-10} \mathrm{M}\right)$ and this response was blocked by At $\left(10^{-5} \mathrm{M}\right)$. Moreover, in branchial circulation of the eel, a bimodal response to very low concentrations of Ach $\left(10^{-12}-10^{-10}\right.$ $\mathrm{M})$ and a dilation response at higher concentrations which produced a contraction, were both blocked by atropine $\left(10^{-5} \mathrm{M}\right)$ (Pellegrino et al., 2002). This effect could suggest the presence of two muscarinic receptors with different sensitivities and functions. The second response observed in our preparation at concentrations between $10^{-6}$ and $10^{-3}$ is in agreement with a low sensitivity. The range described in our study was similar to that described in vascular ring preparations between the ranges of $10^{-8}$ to $10^{-6} \mathrm{M}$ (coronary, celiac mesenteric, central aorta, efferent branchial artery) in trout (Olson and Villa, 1991; Small et al., 1990) and in the ventral aorta in sharks (Evans and Gunderson, 1998a, b). In addition, all previously described studies found only one component in the CRC to Ach. In our study, both responses (high and low sensitivities) were abolished by the use of At $\left(10^{-5} \mathrm{M}\right)$. This evidence is corroborated by other studies in trout, shark and eel (Nilsson and Grove, 1974; Small et al., 1990; Pellegrino et al., 2002, 2003), suggesting the presence of muscarinic receptors in fish vasculature.

Five muscarinic receptors in vascular smooth muscle have been identified by functional, pharmacological and molecular studies in a variety of mammalians and fish (agnathians, elasmobranch and teleosts) (Hulme et al., 1990; Caulfield, 1993; Eglen et al., 1996; Ehlert et al., 1997, Evans and Gunderson 1998a). In mammals, Ach induces vascular smooth muscle relaxation by activation of muscarinic receptors expressed in endothelial cells (Furchgott and Zawadzki, 1980). Molecular approach has demonstrated the presence of muscarinic receptors type 1-3 in arterial vessels (See review, Kawashima and Fujii, 2008). Furthermore, pharmacological studies support the presence of functional muscarinic receptors type 1 and 3 (Norel et al., 1996). Additionally, studies performed in human pulmonary arteries suggest the presence of muscarinic receptor type 3 in smooth muscle mediating the Ach-induced contraction, and muscarinic receptors type 1 are involved in the endothelium-dependent Achinduced relaxation (Norel et al., 1996). In fish, Ach induced contraction in all the species studied so far (Small et al., 1990; Olson and Villa, 1991; Miller and Vanhoutte,1992; 
Evans and Gunderson, 1998a). This contractile response was found even in the presence or absence of endothelium (Miller and Vanhoutte, 1986, 1992, 2000; Olson and Villa, 1991; Evans and Gunderson, 1998b). Furthermore, a pharmacological study conducted in sharks found the presence of functional muscarinic receptors type 1 and 3 , and non functional muscarinic receptors types 2 and 4 (Evans and Gunderson, 1998a).

\subsection{Acetylcholine-cyclooxygenases vasoconstriction pathway}

Our results demonstrate that the Ach-mediated vasoconstriction in all the vessels studied (ABA, EBA, $\mathrm{MA}$ and DA) was abolished with $\operatorname{At}\left(10^{-5} \mathrm{M}\right)$, indicating the presence of muscarinic receptors that promote vascular vasoconstriction in fish. However, when vessels were blocked by IND $\left(10^{-5} \mathrm{M}\right)$, the high sensitivity Ach-mediated vasoconstriction, previously described, was practically abolished in all the vessels studied, suggesting a coupling mechanism between activation of muscarinic receptors with the production of vasoconstrictor prostanoids mediated by COX in Girella laevifrons. This effect did not modify the low sensitivity Ach-mediated vasoconstriction suggesting that this mechanism is mediated by muscarinic receptors in the vascular smooth muscle present in all the vessels studied. The coupled Ach-COX contraction described in our study in fish is similar to that reported in human hypertension or hypertension model in rats (Vanhoutte et al., 2005; Shi et al., 2008). In addition, studies in aortas of a spontaneous hypertension rat model found that inhibitors of COX1 rather than COX2 prevented the endothelium dependent contractions to Ach (Ge et al., 1995) supporting the presence of prostanoid vasoconstrictors coupled to stimulation with Ach. Unfortunately, we did not study specific inhibitors of COX or with endothelium denudate in order to corroborate the participation of endothelium in this response. By contrast, in shark (Squalus acanthias) or trout, it has been shown that an endothelium-dependent dilation in the presence of a calcium -ionophore (A-23187) promoted dilation by a prostaglandin and not by NO (Evans and Gunderson, 1998b; Olson and Villa, 1991; Miller and Vanhoutte, 2000) suggesting the presence of dilation mediated by prostanoids (Evans and Gunderson, 1998b; Miller and Vanhoutte, 2000).

In conclusion, we propose that the intertidal fish G. laevifrons have muscarinic receptors type 1 and 3 with one muscarinic receptor having a high sensitivity that could be located in the endothelium coupled to COX that produce a prostanoid vasoconstrictor, and another muscarinic receptor having a low sensitivity located in the vascular smooth muscle. However, the type of muscarinic receptor and mechanisms underlying this response still needs to be evaluated.

\section{Acknowledgments}

We are grateful for the technical assistance of Mr. Hervis Galleguillos and the students of medicine Carolina Norero, Daniela Gonzalez, Natalia Soto and Marietta Nuñez who collaborated in the experiments. This research was partially supported by project DGIP 10301272 VRA_Universidad Católica del Norte-Chile.

\section{References}

Caulfield, MP., 1993. Muscarinic receptors: characterization, coupling and function. Pharmacology \& Therapeutics, vol. 58, no. 3, p. 319-379. http://dx.doi.org/10.1016/0163-7258(93)90027-B. PMid:7504306

Eglen, RM., Hegde, SS. and Watson, N., 1996. Muscarinic receptor subtypes and smooth muscle function. Pharmacological Reviews, vol. 48 , no. 4, p. 531-565. PMid:8981565.

Ehlert, FJ., Ostrom, RS. and Sawyer, GW., 1997. Subtypes of the muscarinic receptor in smooth muscle. Life Sciences, vol. 61 , no. 18, p. 1729-1740. http://dx.doi.org/10.1016/S00243205(97)00433-5. PMid:9365220

Evans, DH. and Gunderson, MP., 1998a. Functional characterization of a muscarinic receptor in the smooth muscle of the shark (Squalus acanthias) ventral aorta. Experimental Biology Online, vol. 3, no. 3, p. 1-7. http://dx.doi.org/10.1007/s00898-998-0003-5.

Evans, DH. and Gunderson, MP., 1998b. A prostaglandin, not NO, mediates endothelium-dependent dilation in ventral aorta of shark (Squalus acanthias). The American Journal of Physiology, vol. 274, no. 4 Pt. 2, p. R1050-R1057. PMid:9575968.

FURCHGOTT, RF. and ZAWADZKI, JV., 1980. The obligatory role of endothelial cells in the relaxation of arterial smooth muscle by acetylcholine. Nature, vol. 288, p. 373-376. http://dx.doi. org/10.1038/288373a0. PMid:6253831

Ge, T., Hughes, H., Junquero, DC., Wu, KK., Vanhoutte, PM. and Boulanger, CM., 1995. Endothelium-dependent contractions are associated with both augmented expression of prostaglandin $\mathrm{H}$ synthase- 1 and hypersensitivity to prostaglandin $\mathrm{H} 2$ in the SHR aorta. Circulation Research, vol. 76, no. 6, p. 1003-1010. http:// dx.doi.org/10.1161/01.RES.76.6.1003. PMid:7758154

Hulme, EC., Birdsall, NJM. and Buckley, NJ., 1990. Muscarinic receptor subtypes. Annual Review of Pharmacology and Toxicology, vol. 30, no. 1, p. 633-673. http://dx.doi.org/10.1146/annurev. pa.30.040190.003221. PMid:2188581

Kawashima, K. and Fujii, T., 2008. Basic and clinical aspects of non-neuronal acetylcholine: overview of non-neuronal cholinergic systems and their biological significance. Journal of Pharmacological Sciences, vol. 106, no. 2, p. 167-173. http://dx.doi.org/10.1254/ jphs.FM0070073. PMid:18285657

Miller, VM. and Vanhoutte, PM., 1986. Endothelium-dependent responses in isolated blood vessels of lower vertebrates. Blood Vessels, vol. 23, no. 4-5, p. 225-235. PMid:3490888.

Miller, VM. and Vanhoutte, PM., 1992. Endothelium-dependent vascular responsiveness: evolutionary aspects. In RYAN, US. and RUVANYI, GM. Endothelial regulation of vascular tone. (Eds.). New York: Marcel Dekker. p. 3-20.

Miller, VM. and Vanhoutte, PM., 2000. Prostaglandins but not nitric oxide are endothelium-derived relaxing factors in the trout aorta. Acta Pharmacologica Sinica, vol. 21, no. 10, p. 871-876. PMid:11501036.

Muñoz, A. and Ojeda, FP., 1997. Feeding guild structure on a rocky intertidal fish assemblage in central Chile. Environmental Biology of Fishes, vol. 49, no. 4, p. 471-479. http://dx.doi. org/10.1023/A:1007305426073. 
Nilsson, S. and Grove, DJ., 1974. Adrenergic and cholinergic innervation of the spleen of the cod: Gadusmorhua. European Journal of Pharmacology, vol. 28, no. 1, p. 135-143. http://dx.doi. org/10.1016/0014-2999(74)90124-1. PMid:4430318

Norel, X., Walch, L., Costantino, M., Labat, C., Gorenne, I., Dulmet, E., Rossi, F. and Brink, C., 1996. M1 and M3 muscarinic receptors in human pulmonary arteries. British Journal of Pharmacology, vol. 119, no. 1, p. 149-157. http://dx.doi.org/10.1111/j.1476-5381.1996. tb15688.x. PMid:8872368

Ojeda, FP., Labra, F. and Muñoz, A., 2000. Patrones biogeográficos de lospeceslitorales de Chile. Revista Chilena de Historia Natural, vol. 73 , no. 4 , p. $625-641$

Olson, KR. and Villa, J., 1991. Evidence against endotheliumderived relaxing factor(s) in trout vessel. The American Journal of Physiology, vol. 260, no. 29, p. 925-933.

Pellegrino, D., Sprovieri, E., Mazza, R., Randall, DJ. and Tota, B., 2002. Nitric oxide-cGMP-mediated vasoconstriction and effects of acetylcholine in the branchial circulation of the eel. Comparative Biochemistry and Physiology. Part A, Molecular \& Integrative Physiology, vol. 132, no. 2, p. 447-457. http:// dx.doi.org/10.1016/S1095-6433(02)00082-X. PMid:12020661

Pellegrino, D., Acierno, R. and Tota, B., 2003. Control of cardiovascular function in the icefish Chionodraco hamatus: involvement of serotonin and nitric oxide. Comparative Biochemistry and Physiology. Part A, Molecular \& Integrative Physiology, vol. 134, no. 2, p. 471-480. http://dx.doi.org/10.1016/S10956433(02)00324-0. PMid:12547277

Pulgar, J., Bozinovic, F. and Ojeda, FP., 1999. Behavioral thermoregulation in the intertidal fish Girella laevifrons
(Kyphosidae): the effect of starvation. Marine and Freshwater Behaviour and Physiology, vol. 32, no. 1, p. 27-38. http://dx.doi. org/10.1080/10236249909379035.

Shi, Y., Man, RY. and Vanhoutte, PM., 2008. Two isoforms of cyclooxygenase contribute to augmented endotheliumdependent contractions in femoral arteries of 1-year-old rats. Acta Pharmacologica Sinica, vol. 29, no. 2, p. 185-192. http:// dx.doi.org/10.1111/j.1745-7254.2008.00749.x. PMid:18215347

Small, SA., MacDonald, C. and Farrell, AP., 1990. Vascular reactivity of the coronary artery in rainbow trout (Oncorhynchus mykiss). The American Journal of Physiology, vol. 258, no. 6 Pt. 2, p. R1402-R1410. PMid:2360689.

Stassen, FR., Raat, NJ., Brouwers-Ceiler, DL., Fazzi, GE., Smits, JF. and De Mey, JG., 1997. Angiotensin II induces media hypertrophy and hyperreactivity in mesenteric but not epigastric small arteries of the rat. Journal of Vascular Research, vol. 34, no. 4, p. 289-297. http://dx.doi.org/10.1159/000159236. PMid:9256089

Urriola, N. and Moraga, FA., 2008. Comparative study of cholinergic responses in doral artery between intertidal fish Girella laevifrons and subtidal fish Isacia conceptionis. Revista de Farmacologia de Chile, vol. 1, no. 1, p. 94.

Varas, E. and Ojeda, FP., 1990. Intertidal fish assemblage of the central Chilean coast: diversity, abundance and trophic patterns. Revista de Biologia Marina, vol. 25, p. 59-70.

Vanhoutte, PM., Feletou, M. and Taddei, S., 2005. Endotheliumdependent contractions in hypertension. British Journal of Pharmacology, vol. 144, no. 4, p. 449-458. http://dx.doi.org/10.1038/ sj.bjp.0706042. PMid:15655530 